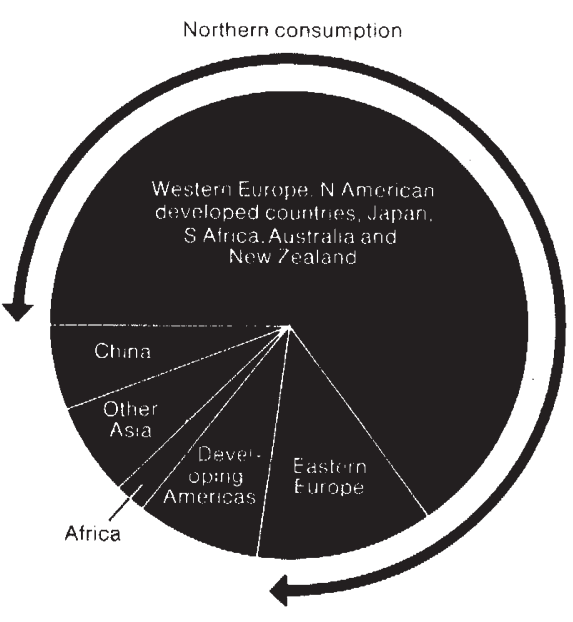

World pharmaceutical consumption for 1980 (total $\$ 76,000$ million, manufacturer's prices.

Health Organization (WHO) has put considerable effort into work on new medicines and vaccines for diseases such as malaria, onchocerciasis, leprosy and leishmaniasis, but the report argues that the commercial companies cannot take on work on new drugs for these diseases because of the harsh economic realities of the marketplace - the return from sales of "'Third World-oriented" drugs would not cover the cost of their development.

Thus OHE argues that the major drug companies should be used as contractors by WHO and governments to carry out the expensive first stages of developing drugs for diseases in developing countries. It is argued that this approach would be the most cost-effective way for the developed nations to help the poorer nations achieve better health standards.

To put the expenditure involved in finding new drugs into context, the total research and development spending by the UK pharmaceuticals industry is around $£ 300$ million per year, compared with the $£ 1,000$ million spent annually by the UK government on overseas aid. So an increase of just 5 per cent in this aid budget would provide $£ 50$ million, which if spent on contracted research could support a significant effort to find drugs important to developing countries.

On the supply of existing medicines to the developing countries, the OHE report is critical of the WHO programme on "essential" drugs. As for policing the marketing and advertising methods used to promote drugs in the Third World, OHE sees the international code of marketing practice drawn up recently by the International Federation of Pharmaceutical Manufacturing Associations as the best hope for the future. The federation, it is argued, would be well able to regulate the activities of the major international companies because it is in the companies' interest to be seen to be acting responsibly throughout the world. WHO is seen by the industry as being open to political pressures and therefore ineffectual as a controlling body.

\section{US weather and ocean research Outlook bleak}

\section{Washington}

The major controversy in Washington this week has been the fate of the federal budget, as congressional leaders and the President joust with each other, leaving the outcome in doubt. No less concerned are the atmospheric scientists and oceanographers, especially those involved in international programmes, many of which have been cut back in the President's proposed budget. Ocean and atmospheric research has always had friends in Congress, and they are trying to have the funds restored. But whether the money can be put back, and then retained in a final budget package, is in doubt.

Marked for the axe are funds for joint US-Canadian efforts to clean up the Great Lakes, half of the satellite capability that provides weather data to nations in Asia, Africa and South America, funds to study and prevent ocean dumping (including radioactive waste), and the World Climate Program, the successor to the Global Atmospheric Research Program, which is a major international effort run from Geneva.

The Canadian government has been very upset about the proposed cut-back in US efforts to help study, monitor and clean up the Great Lakes, to which the US government is committed under several agreements with Canada. Under the proposed Reagan budget, two laboratories would be closed down and one programme office severely curtailed.

One laboratory is run by the Environmental Protection Agency (EPA) at Grosse Ile, Michigan, near Detroit. The other is run by the National Oceanic and Atmospheric Administration (NOAA) at Ann Arbor, Michigan.

The Administration justifies the cuts by claiming that most of the research needed to identify Great Lakes pollution has been done, and that cleaning up is a responsibility of the states that border them.

But the Canadian government's view is that still more pollution problems are being unearthed, such as the identification and reduction of such toxic substances as mirex and dioxin which have recently been found in "hot spots" in all the lakes except Lake Superior, and that the international commitments are federal, not state, issues. According to one Canadian official the cuts amount to "an attempt by the United States to renege on its water quality agreement of 1978' with Canada. This is strong language, given the historical close cooperation between the two countries at least until the advent of the acid rain dispute and the Great Lakes budget cuts.

The Administration also wants to cut NOAA funds for ocean dumping research and marine pollution generally. NOAA runs most of the government's research in this area. The work concentrates on the area off the north-east coast of the United States which has the worst pollution problem, a major fishing ground and possible oil development. The rationale for the cut is that northeastern states should individually bear these costs. Congressmen seeking to restore the funds argue that these are national problems, especially in the light of renewed talk of disposing of radioactive and other forms of waste in the oceans.

For the second year in a row, the Administration has tried virtually to eliminate one of the ocean research programmes most popular on university campuses in the United States, the \$35 million per year Sea Grant programme. For 1983, the Administration proposes only $\$ 1.7$ million. However, as in 1982 , representatives and senators are expected to get the funds restored. About half of the Sea Grant funds go for research, and the other half for community services related to the oceans issue.

The proposed Administration budget would also cut $\$ 6$ million of the $\$ 7$ million going to weather modification research, as part of a 40 per cent cut in atmospheric research funds. Likewise, a programme to upgrade the old weather radars on which continental US weather forecasting relies heavily is being slowed drastically. The Administration contends that weather is a local issue. Friends of NOAA counter, however, that weather modification and atmospheric research are important basic research programmes.

Of worldwide interest is a cut of $\$ 24$ million that would decrease the launch rate of the NOAA series of polar-orbiting weather satellites, so that there would be one instead of two in orbit at any given time. These satellites complement the existing two GEOS geosynchronous satellites that provide "side views" of the Earth's weather, including the familiar television-screen images, to many countries that have receivers.

Representative James H. Scheuer, chairman of the House Science and Technology Committee's subcommittee on natural resources, agriculture research and environment, is trying to get the second NOAA satellite restored.

Scheuer argues that while the geosynchronous satellites indicate current weather, mostly in the middle and lower latitudes, the polar-orbiting satellites are essential to forecasting worldwide. Only they can acquire the quantitative data needed for modelling the Earth's weather, and only they can track the Arctic and Antarctic air masses moving towards the inhabited regions. The NOAA series satellites are thus crucial to weather prediction in parts of the world, such as Asia, Africa and Australia, that other satellites do not "look at" as often as at North America and Europe.

Two satellites provide twice as many passes over a region as one, and so improve 
daily forecasting. Two satellites also provide for redundancy. Scheuer says the Administration's cut will reduce the timeliness of forecasting and leave those parts of the world that are "neglected" by the rest of the system without any weather information at all when the remaining satellite breaks down - which happens often enough. Sometimes it takes a year to put a replacement for a broken satellite in orbit.

Finally, funds for the US contribution to the World Climate Program, a major international climatological effort run in cooperation with the World Meteorological Organization, have been cut from $\$ 1.8$ million to $\$ 0.5$ million.

Deborah Shapley

Lead in petrol

\section{Clear risks}

The British anti-lead lobby is flying high. Results now emerging from recent studies seem to be persuading scientific and medical opinion that the government should take further action on the lead content of petrol. Total elimination was advocated by many of the participants at an international conference organized last week by the Campaign for Lead Free Air (CLEAR).

Local councillors, civil servants and scientists from several countries heard evidence that children's IQ is impaired by low blood lead levels and that a significant contributor to lead burden is the lead in petrol. Des Wilson, chairman of CLEAR, is confident that the conference was given conclusive evidence that the position of the government is becoming increasingly isolated and untenable. The Lawther report, he said, had been completely discredited.

In 1980 a working party under the chairmanship of Professor P.J. Lawther advised that the evidence on danger from low blood lead levels was inconclusive. The Lawther working party also recommended that most effort be directed to reducing the lead in food and water, on the grounds that lead in petrol did not make the most significant contribution to the body lead burden.

The fear that blood lead concentrations of $300 \mu \mathrm{g} \mathrm{l}^{-1}$ and below may have neurological effects represents a gradual shift of opinion over the past two years. The official government position is that harmful effects do not occur below $350 \mu \mathrm{g}$ $\mathrm{I}^{-1}$. The change of heart by the government which resulted in the decision last year to cut the legal amount of lead in petrol from $0.4 \mathrm{mg}$ per litre to $0.15 \mathrm{mg}$ per litre was in keeping with the Lawther case tor a progressive reduction. Professor Lawther now says that the elimination of lead in petrol did not conflict with the findings of his working party and that "if there were damn all, nobody would be happier than me".

While there is no dispute about the toxic effects of lead at high levels, controversy persists about the level at which harmful effects occur. After the Lawther working party reported, two members, Dr Richard Lansdown and Dr William Yule of the Institute of Psychiatry and Great Ormond Street Hospital for Sick Children, produced results suggesting a link between blood lead levels and IQ performance in children of the London suburb of Greenwich and claimed a significant difference of IQ performance with blood lead above and below $120 \mu \mathrm{g} \mathrm{l}^{-1}$ (Devl Med. Child Neurol. 23, 567-576; 1981).

At last week's symposium, Yule and Lansdown gave new evidence (as yet unpublished) that children's behaviour is related to blood lead levels -19 per cent of those with blood lead levels above the average $\left(120 \mu \mathrm{g} \mathrm{l}^{-1}\right)$ were overactive compared with only 4.9 per cent of those with blood lead levels below the average. Bad conduct, nervous tension and lack of concentration increased with higher blood lead levels. Professor Herbert Needleman (Children's Hospital, Pittsburgh) also reported an association between classroom behaviour, IQ performance and lead burden.

Others say, however, that there should be extreme caution in moving from an observation of correlation between childhood lead exposure and impairment of intellectual development to postulating lead as the cause of extreme behavioural and psychological damage. The social environment is an extremely important factor in IQ performance.

The conference was also told of the significant contribution of lead in petrol to lead burden, making the Lawther estimate of 10 per cent seem too low. One recently completed study by the EEC Joint Research Centre at Ispra, Italy, suggests that as much as 30 per cent of the lead in blood is derived from petrol. The study determined the contribution of lead from petrol by relying on the known abnormal isotopic composition of lead in the petrol in one region of Italy. The conference also heard that in the United States in the four years since the phasing out of lead in petrol (1976-80), blood lead levels had fallen by 36.7 per cent. Dr Clair Patterson (California Institute of Technology) said that "exhausts from leaded gasolines are the most serious sources of lead in people".

While opinion is still divided and the need for further research acknowledged, Professor Michael Rutter (Institute of Psychiatry, London), a member of the Lawther committee, came down firmly in favour of the elimination of lead from petrol: "the level of probability is such that I think it is worth acting on".

CLEAR moves confidently into battle having already captured the support of the Labour party. The National Executive Committee pledged last month that a future Labour government would eliminate lead in petrol. CLEAR's sights are now set on the party conferences where it is confident of rallying support from the other opposition parties.

While much of the new evidence is not yet published, the Royal Commission on Environmental Pollution has now also launched an investigation into lead. It has heard evidence from the British Medical Association (BMA) supporting the link between low blood lead levels and impaired mental function. The BMA also appears to be convinced by the Ispra study.

The Royal Commission plans to investigate the sources of lead in the environment and its pathways to man. The commission also plans to "get to the bottom" of arguments about the technical and economic implications of reducing lead in petrol below that promised by the government last year. The commission may be confronted with strongly held opinions Des Wilson described Associated Octel, the British company owned by Shell, BP, Chevron, Mobil and Texaco, which supplies the lead for petrol, as "the biggest mass child poisoners in the world today".

The oil companies say, however, that they will cooperate with the government if it calls for a ban on lead in petrol. The buck has now been passed.

Jane Wynn

\section{Enter Exxon}

\section{New York}

Cold Spring Harbor Laboratory on Long Island, New York, has agreed to a five-year "cooperative research agreement" with Exxon Research and Engineering Company. However, the financial terms of the deal are not being disclosed by Exxon, which is making its debut into the overcrowded world of biotechnology.

Under the terms of the agreement, up to six Exxon scientists will be assimilated into the Cold Spring Harbor staff to work full time on mutually agreed projects. In return, Cold Spring Harbor will select six postdoctoral fellows to participate in Exxon-funded research. In addition, Exxon's biosciences laboratory in New Jersey (which has never worked on molecular biology) may consult Cold Spring Harbor on various matters.

Exxon plans that its lawyers will visit the Cold Spring Harbor Laboratory regularly to keep abreast of latest developments. It will have exclusive rights to all patents derived from the research it funds, while Cold Spring Harbor Laboratory will retain rights to patents derived from work done by staff members not associated with Exxon projects.

Exxon will not ask those working on its Cold Spring Harbor Laboratory projects to defer publication of patentable inventions, as some industrial sponsors have requested of academic institutions relying on their funds.

Michael D. Stein 